\title{
NATIONAL CURRICULUM 2013: FROM LITERACY TO SCIENTIFIC APPROACH
}

\section{Rohib Adrianto Sangia}

Abstract: Implementation of the newest National Curriculum 2013 in every public school gives problem to the teacher's way of thinking especially for language teacher. It is projected to change the language teaching paradigm from literacy approach which gives the students opportunity to use the information from what they read and write to scientific approach that gives students chance to develop their intelligence to higher order thinking in learning language and expected in using it in proper way as life skills equipment in facing the rapid changes of global society system in the near future. Copying this fact about this new curriculum, this article is trying to describe deeper about new feature that brought by curriculum 2013. The aspects start from the concept of curriculum, the assessment process, the learning process namely scientific approach which can be implemented by using some procedures in the classroom and the textbook.

Keywords: Curriculum 2013, scientific approach, language learning, textbook

Curriculum is a product of education policy that has to change all the time. In reality, it is not tended to change but rather to make improvement. The continuous improvement which is conducted has purposed to accommodate the material which is considered important and up-todate. The improvements are conducted as implementation of one of curriculum development principle that a curriculum should be dynamic and flexible, so it can be change anytime according to the need (Sukmadinata, 2007: 109). In order to fulfill the need of the society, the curriculum changes should be done gradually and systematically.

The curriculum change is not only happened in Indonesia, but also in another modern country, since it is changed depend on the needs. The curriculum change is accepted in various countries normally and naturally. It is different with the negative view of ordinary people in Indonesia. This point of view should be straightened by looking at positive side that the change or improvement of curriculum cannot be stopped, and always be done because of the society needs (Katuuk, 2014: 13), knowledge, technology, art and culture.

The previous curriculum change before Curriculum 2013 was held in 2006, which is set by National Education Ministry with some purposes which are improving the quality of education through self-reliance and initiative in developing the school curriculum, manage and empower the available resources; raising people's awareness of the school and the community in developing the curriculum through shared decision returns; and increasing the fair competency among educational units to be achieved (Widuri, 2012: 8). After all, the one of crucial purpose of English language learning for senior high school is directing the student to develop their language skills so that graduates are able to communicate and dialogue in English on certain literacy level (Badan Standar Nasional Pendidikan, 2006: 125). 
In KTSP, It has been pointed that literacy level is an orientation and indicator of English language learning activity that has to be mastered by student in certain level of school. Mohanty (2007: 64) describe literacy now days not only read and write, but also beyond those are. It is more specific to skills in applying and developing their knowledge from what they read and write in order to give contribution to global society. As a fact, Literacy approach had been introduced in Curriculum 2004 in English language learning as the solution in facing the challenging of world and language discourse in the near future (Kumalarini and Munir, 2006: 40). Later in curriculum KTSP Wijayati (2011: 58) had pointed out that School based Curriculum is still using literacy approach in order to stimulate and activate the English teaching four skills based. There are four stages or levels of literacy skills which was proposed by Wells (1987) cited by Finn (2009: 124). They are performative level as a standard for SD, functional level as a standard of SMP, informational level as standard of SMA and Epistemic level which is expected for under graduate.

\section{Why curriculum 2013, and what does it bring?}

As changes occur, the minister education and culture, Mohammad Nuh has made new changes to the curriculum called the curriculum 2013. As cited by Katuuk (2014:14), there are two objective reason why the minister intended to change to the existing curriculum. First, prepare the Golden Generation Indonesia for a hundred years of independent Indonesia. Entering a hundred years of Indonesian independence (2045), the population of present students would have aged 35-44 years and 45-54 years. This group is a group of people that are in the reproductive age and is a prospective leaders. Because it is a strategic age group, they should be prepared as early as possible.

The second reason is the preparation of Indonesia's ability to deal with the problems associated with globalization: WTO, ASEAN Economic Community, APEC, CAFTA; environmental issues; advances in information technology; convergence of science and technology; knowledgebased economy; the rise of the creative and cultural industries; change of world economic power; quality, investment and transformation of the education sector. Demands of global developments produced a generation that has a need for competitive ability and the ability to solve difficult challenges in the future.

Kasim (2014: 26), the vice minister of education and culture for education affairs in his slides, noted that the latest curriculum has four basic different with it precursor. The basic differences are the concept of curriculum, the assessment process, the learning process and the textbook. The concept of curriculum 2013 was explained contradictory by AR (2013). She claimed that the concept of Curriculum 2013 had been developed and implemented in the previous curriculums (AR, 2013: 3). Furthermore she added that the point of curriculum 2013 is there is an effort from the government to simplify of curriculum in thematic and integrated. While Kasim (2014: 26) argued that the concept of curriculum 2013 which cannot find in the previous curriculum is more purposeful in balancing between hard skills and soft skills, starting from standard of competency, standard of content, standard of process, and standard of 
assessment in order to produce the better output. After all, the most concerned thing of the improvement is the attached of the character building in every school subject, which expected to improve the students' attitude. That is why it is not surprised when we found the competence for English subject $10^{\text {th }}$ level stated "Filling grateful to learn English as a communication tool for the international scope." The character building substance will give some impact to assessment process as result of the demand of authentic assessment.

Priyanto (2013: 11) mentioned that one of keyword of curriculum 2013 is authentic assessment. Authentic assessment is a comprehensive assessment conducted to assess the input, process, and output includes learning attitudes, knowledge, and skills (Prasetyo, 2014: 10). There are four types of authentic assessment in the curriculum 2013. They are performance assessment, project assessment, portfolio assessment, and written assessment (Armina, 2013: 24). Performance assessment is an assessment that requires students to demonstrate a particular competency. To assess the language skills of learners, from the aspect of speaking skills for example teachers can observe dialog, discussions, storytelling, and interviews from the students. The project assessment is the assessment of the tasks to be completed by students by period / specific time. Completion of the task is in the form of investigations conducted by students ranging from planning, data collection, organization, processing, analysis, and presentation. Portfolio assessment is an assessment of the collection of artifacts that show progress and appreciated the work of the real world. Written assessment is an assessment in the form written of a description or essay that requires students are able to remember, understand, organize, implement, analyze, synthesize, evaluate, and so on top of the material that has been studied. Such tests provide an opportunity for teachers to be able to measure the learning outcomes of students at a higher level or complex.

Character building material in curriculum 2013 has been defined well by adding it in the competency of every subject. It means that it has an obvious instrument how to measure this kind of competency clearly which cannot be found in the previous curriculum. After all, for the rest learning process and the textbook.

\section{Language learning process with scientific approach}

The process of learning in the curriculum in 2013 is expected to create learning that allows educators to collaborate and share good experiences with other educators and with the learners. In addition, the expansion of the learning process is expected to take place in the learning community involvement. In order to be on the point of achieving the goals of learning the language, of course, we need a variety of formulas or approaches for the study. This is consistent with Gardner (2009: 107) submitted that it should be able to master a set of basic teaching curriculum materials and a number of approaches, it also means that it is not bound by the requirement for a particular principle.

By looking at Salinan Lampiran Permendikbud Nomor 65 Tahun 2013, there are three approaches that compulsory to use. They are scientific approach, integrated thematic approach and thematic approach. From those approaches, the government claimed that the scientific 
approach is the new approach that is reliable to handle the entire subject. Thus, scientific approach is used to entire subjects especially in junior and senior high school (Cahyani, 2013: 141).

Scientific approach is a major approach in curriculum 2013 which is actually equalizing the learning process paired with a scientific process (Sudio cited in Sari, 2013: 193). Scientific approach is an approach that emphasizes inductive rather than deductive reasoning. Thus, by using the scientific approach, students are encouraged to engage directly in the process of acquiring knowledge. Therefore, the application of this approach will touch the three domains, namely attitudes, knowledge, and skills. Learning outcomes-based scientific approach will create the students who are productive, creative, innovative, and effective through the strengthening of attitudes, skills, and knowledge are integrated.

Many experts believe that the scientific approach makes students more active in constructing knowledge and skill. It can also encourage students to conduct an investigation in order to find the facts of a phenomenon or event. It means in the learning process, students is taught and adapted to finding scientific truth, not to make opinion by view a phenomenon. They are trained to be able to think critically, hypothetically, analytically, logically, chronologically, objectively and systematically (Wikanengsih, 2013: 335). Those kinds of thinking are expected to prepare the student in achieving high order thinking.

\section{Implementing scientific approach in language learning}

The government claimed that the learning process by using scientific learning gives more significant result that non-scientific learning (Kementerian Pendidikan dan Kebudayaan, 2013a: 152). They believe that as long as the learning using scientific approach by using the principles in scientific process, meaningful learning can be achieved, since students as the actor of the knowledge discovering. From this kind of learning, the finding of the experiment reveals the level of student receiving and understanding increase twice than conventional method.

Basically, the scientific approach has some major sequences or steps in getting learning experiences. They are observing, questioning, associating, experimenting and networking (Kementerian Pendidikan dan Kebudayaan, 2013a: 155). In observation, students and teachers are provided with objects, real objects, or phenomena. Students are directly involved in learning. It helps teachers to contextualize students' learning in the classroom. At the same time, students can learn based on what they see to construct their knowledge. It also facilitates students to fulfill their need of knowing something. In this context, their curiosity will lead them to the construction of knowledge. Contextually is also present because students can connect what they have learned with what they are going to learn.

Questioning is a powerful teaching technique that has been used for years since it was firstly introduced by Socrates (DeLandtsheer, 2011: 101). Questioning can be used by both teachers and students in the classroom. What are the purposes of teachers' classroom questions? A variety of purposes emerge from analysis of the literature. Associating is the process of thinking 
logically and systematically over - the empirical facts that can be observed in the form of knowledge to obtain conclusions. In the context of learning, associating is focused on students' learning activities. Experiments make students understand the concepts of language and its relation to everyday life. The application of experimental methods is intended to develop various learning objectives, the attitudes, skills, and knowledge. Networking is also called collaborative learning which is more than just learning techniques in the classrooms. Collaboration is the essence of philosophy and lifestyle of human interaction that places and facilitates collective efforts in order to achieve common goals. For teachers, the collaborative learning function is more directive oriented in which the teachers are managers in the students' learning. Here, the students are those who are active. In a collaborative situation, the learners interact with empathy, mutual respect, and receive a deficiency or excess, respectively. This allows the learners to face various changes and challenges to learn together.

In this case, this article will expand the sequences with simulation of simple scientific approach language learning process for junior high school material about short functional text. The material is "writing an email" with some purposes of study which are (1) students can identify the meaning and language elements contained in a letter or email; (2) students can arrange draft letters or emails politely according to the social norms in groups; (3) students can write a letter or emails correctly and properly.

For teaching writing competence which is focused in writing a short email, teachers need to prepare some materials in order to help the student understanding the text. The suggested materials are the new vocabularies which are relevant and common in the email, some expression which has function as gambits in writing (Fauziyah, 2012:11), and a complete email as model in learning how to write an email. Since writing is a complex process from all the language aspect and skills, it needs trial and error to the student and it should be anticipated by the teacher.

Concerning the process of teaching in the classroom, the government by the regulation (Kementerian Pendidikan Dan Kebudayaan, 2013b: 8) has determined the proper classroom scenario. The suggested lesson plan to teacher, describe that there are three major steps of activities in the classroom which should be managed appropriately by teachers which are preliminary activities, core activity and closing activity.

In preliminary activity, there are several activities that can be conducted by teacher (Kementerian Pendidikan Dan Kebudayaan, 2013b: 8). The first is preparing students psychologically and physically to participate in the learning process such as praying for example. Then, teacher should motivate students to learn the benefits and contextually appropriate teaching materials applications in everyday life, by giving example and describing comparison from local, national to international scope. The third is asking questions about earlier knowledge that link the material which will be studied. The last, teachers do not forget to explain the purpose or direction and also the scope of material that students are expected to achieved from the learning process. 
The core activity is the place that scientific approach is implemented(Kementerian Pendidikan Dan Kebudayaan, 2013b: 9). It means that, the procedures would be conducted in sequence. The first sequence is observing. In observing, by using the textbook from government, teacher guides the student to open the pages which contains the material and gives students some times to observe several mails in the book by reading and understand it. From the mails, students are stimulated unconsciously to find the differences and similarities from the mails in many aspects. After that, teacher starts to help the students to observe deeper by giving the clue of identification, such as structure, vocabularies, gambits, etc. in the texts.

The second sequence is questioning what the students observed. The question ideally should come from the students about the problem in reading, understanding or identifying the texts. But sometimes, they do not ask with many factors. Maybe they have understood about the texts or maybe they are really not understood so they are reluctant to give some feedback about the texts as object of observation. The silence of students should be responded by teacher by giving some stimulant question to assess the students understanding to the texts (Tisnasari, 2013: 278). The questions as stimulan from the teacher are expected to make students responds and trying to explore the texts in details.

The next sequence is associating the object which has observed. From the concepts of mails which has explore before by observing and questioning, students are expected to think higher in identifying parts of mail by associating with mails. In example, students know where to find the place of mail's sender or receiver, date, or more, the place which contained the point of the mail or email. Students can associate the parts of mail or email as the result of previous sequence. It means, if there is a problem in associating the objects, so the teacher should repeat the sequence at glance to establish students' concepts. After the students' concepts about the material has constructed, teacher allows to move on experimenting as the next sequence.

The experimenting sequence can be called as assessing or evaluating what students' have achieved in the previous sequence. In this sequence, teacher displays a new mail so that students should understand and identify an email so they can present their analysis in a concept. The task gives students a requirement to start over sequences, from observe to associate without questioning, in order to analyze the new object. Sometimes questioning is still appear, but it is expected to reduce according to the students' understanding level. From some experiments, teacher can analyze the students' capability and capacity to move on the last sequence.

The raw concept of an email that the students' learned before is discussed. The result of the discus becomes concept and principal to them in producing another object in here an email. The networking sequence is reflected in producing a new object in form of email. Writing a good email based on the students' learning experience means the indicator of the success of learning. Good email in here refers not only from the view of structures and vocabularies but also the content which is relevant to the previous email that they observed in the first. The relevancy can be realized by producing the respond email, or email with same purpose but different content. 
In the end of learning activities, closing activity covers conclusion, reflection, homework, and preparation for the next meeting (Kementerian Pendidikan Dan Kebudayaan, 2013b: 10). The first part is teacher and students make a short conclusion about what they have learned. The second part is giving sometimes to reflect what they have done by awarding some feedback not only from teacher but also from the students. The students are encouraged to exercise by giving homework as part of an assessment. This homework is anticipated in sharping the students' skills what they just knowledgeable. Finally, it is necessary to remind the students about the next material in next meeting.

From the activities for one meeting above, explain the principle of scientific approach which using sequence in discovering the concept of an object. In the language learning, the objects which observes by the students are about the language product (dialogue, text, etc.), real object, event, phenomena, etc. the scientific approach shows the present of students' effort in discovering the concepts or knowledge. Before the producing process (networking) students' understanding is confirmed by experiments.

\section{Conclusion}

The changing of national curriculum is an effort that cannot be avoided by government in order to improve out-of-date curriculum because of the needs from global rapid transformation. The major changes that happens in the latest curriculum are the concept of curriculum which made lighter, the assessment process that emphasize authentic assessment, the learning process which introduce scientific approach and the textbook which made by government itself.

The change of National Curriculum has produced a new approach in language learning replacing literacy approach. Scientific approach is the latest approach that can be applied in all subject in curriculum 2013 (Cahyani, 2013: 144). This approach is applied by considering the sequences of scientific process in gaining a new experience or knowledge.

Basically, the process of implementing scientific approach in the classroom almost same with the previous suggested method. The significant change is in the core activities. It accommodate the five sequences of scientific behavior in guiding the students discover the knowledge from observing, questioning, associating, experimenting and networking. This various of sequences is expected to increase the students' capacity effectively in gaining better knowledge and learning experience. 


\section{REFERENCES}

AR, Aisyah. 2013. Pelaksanaan Manajemen Pembelajaran Berkarakter Dalam Penerapan Kurikulum 2013 Di Kelas Awal Sekolah Dasar. Paper presented at the Prosiding Seminar Pendidikan Nasional.

Armina. 2013. Penerapan Penilaian Autentik pada Pembelajaran Bahasa Indonesia SMA Sebagai Implementasi Kurikulum 2013. Paper presented at the Implementasi Pembelajaran Bahasa dan Sastra Indonesia Berdasarkan Kurikulum 2013, Bandung.

Badan Standar Nasional Pendidikan. 2006. Standar Isi Untuk Satuan Pendidikan Dasar dan Menengah : Standar Kompetensi dan Kompetensi Dasar SMA/MA. Jakarta: Badan Standar Nasional Pendidikan.

Cahyani, Isah. 2013. Memberdayakan Bahasa Indonesia: Pendekatan Saintifik dalam Pembelajaran Menulis. Paper presented at the Implementasi Pembelajaran Bahasa dan Sastra Indonesia Berdasarkan Kurikulum 2013, Bandung.

DeLandtsheer, John. 2011. Making all kids smarter : strategies that help all students reach their highest potential. Thousand Oaks, CA: Corwin.

Fauziyah, Ida. 2012. Communication Strategies Used in The Interaction Between Tourist Guides and Foreign Tourists in Borobudur Temple. Rainbow: Journal of Literature, Linguistics and Cultural Studies Vol. 1 No. 1.

Finn, Patrick J. 2009. Literacy with an attitude : educating working-class children in their own self-interest (2nd ed.). Albany: State University of New York Press.

Gardner, Howard. 2009. Multiple approaches to understanding. In K. Illeris (Ed.), Contemporary theories of learning : learning theorists in their own words (1st. ed., pp. viii, 235 p.). London: Routledge.

Kasim, Musliar. 2014. Paparan Wamendikbud Konsep dan Implementasi Kurikulum 2013. Jakarta: Kementerian Pendidikan dan Kebudayaan.

Katuuk, Deitje Adolfien. 2014. Manajemen Implementasi Kurikulum: Strategi Penguatan Implementasi Kurikulum 2013. Cakrawala Pendidikan Vol. 1 No. 1, 13-26.

Kementerian Pendidikan dan Kebudayaan. 2013a. Materi Pelatihan Guru Implementasi Kurikulum 2013. Jakarta: Badan Pengembangan Sumberdaya Manusia Pendidikan dan Kebudayaan dan Penjaminan Mutu Pendidikan.

Kementerian Pendidikan Dan Kebudayaan. (2013b). Salinan Lampiran Permendikbud Nomor 65 Tahun 2013 Tentang Standar Proses Pendidikan Dasar Dan Menengah. Jakarta: Kementerian Pendidikan Dan Kebudayaan.

Kumalarini, Th, and Munir, A. 2006. Pemahaman Guru Terhadap Kurikulum 2004 Mata Pelajaran Bahasa Inggris Di SMP Negeri Se-Kota Surabaya. Pendidikan Dasar Vol. 7 No. 1.

Mohanty, Sunil Behari. 2007. Lifelong and adult education. New Delhi: A.P.H. Publishing Corporation. 
Prasetyo, Zuhdan K. 2014. Generasi Emas 2045 Sebagai Fondasi Mewujudkan Siklus Peradaban Bangsa Elalui Implementasi Kurikulum 2013 Di Sekolah Dasar Paper presented at the Seminar Nasional Kurikulum 2013, Universitas Tanjungpura Pontianak.

Priyanto, Agus 2013. Mencipta Sastra (Puisi) dengan Pendekatan IImiah Implementasi Pendekatan Ilmiah (Saintifik) Kurikulum 2013. Paper presented at the Implementasi Pembelajaran Bahasa dan Sastra Indonesia Berdasarkan Kurikulum 2013, Bandung.

Sari, Lusi Komala. 2013. Perkembangan Mutakhir Pembelajaran Bahasa Indonesia: Pendekatan Pembelajaran Bahasa Indonesia. Paper presented at the Implementasi Pembelajaran Bahasa dan Sastra Indonesia Berdasarkan Kurikulum 2013, Bandung.

Sukmadinata, Nana Syaodih. 2007. Kurikulum dan Pembelajaran. In FIP-UPI (Ed.), Ilmu dan Aplikasi Pendidikan Bagian 2 (2 ed., pp. 97-132). Bandung: PT Imtima Grasindo.

Tisnasari, Sundawati. 2013. Pelatihan Strategi Pembelajaran Aktif Inovatif Kreatif Menyenangkan Sebagai Upaya Menyongsong Kurikulum 2013. Paper presented at the Implementasi Pembelajaran Bahasa dan Sastra Indonesia Berdasarkan Kurikulum 2013, Bandung.

Widuri, Endang. 2012. Perbandingan Pengajaran Dengan Menggunakan KBK (Kurikulum Berbasis Kompetensi) Dan KTSP (Kurikulum Tingkat Satuan Pendidikan). Basastra Vol. 1 No. 1.

Wijayati, Maria Goreti Istty. 2011. Case Study Implementation of School Based Curriculum (KTSP) by the English Teacher of SMA Negeri 2 Wonogiri. Humaniora-eJournal Fakultas Bahasa Vol. 3 No. 3.

Wikanengsih. 2013. Pendekatan Scientific Berbasis Gaya Belajar Siswa pada Mata Pelajaran Bahasa Indonesia Sebagai Implementasi Kurikulum 2013 Paper presented at the Implementasi Pembelajaran Bahasa dan Sastra Indonesia Berdasarkan Kurikulum 2013, Bandung. 